\title{
Use of rice husk ash as only source of silica in the formation of mesoporous materials
}

\section{(Emprego da cinza da casca de arroz como única fonte de sílica na formação de materiais mesoporosos)}

\author{
A. J. Schwanke , D. M. A. Melo², A. O. Silva', S. B. C. Pergher

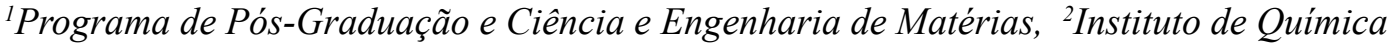 \\ Universidade Federal do Rio Grande do Norte - Campus Universitário Lagoa Nova, Natal, RN 59072-970 \\ anderson-js@live.com,daraujomelo@gmail.com
}

\begin{abstract}
This paper reports the synthesis of molecular sieves similar to MCM-41 using rice husk ash as only source of silica. For comparison purposes, a standard synthesis was performed using aerosil 200 commercial silica. The rice husk silica was obtained by heating treatment at $600{ }^{\circ} \mathrm{C}$ and leaching for $2 \mathrm{~h}$ in reflux with $\mathrm{HCl} 1 \mathrm{~mol} . \mathrm{L}^{-1}$ and used in the synthesis. The samples prepared were characterized by $\mathrm{N}_{2}$ adsorption, X-ray diffraction (XRD), scanning electronic microscopy (SEM) and thermogravimetric analysis (TG). By type-IV adsorption isotherms, the formation of mesoporous materials was observed. XRD showed the formation of hexagonal unidirectional pore materials similar to MCM-41. By SEM, it could be observed that the rice husk has fibrous aspect and that synthesis using calcined and leached rice husk did not react entirely because silica was only partially dissolved.

Keywords: MCM-41, rice husk ash, mesoporous materials.
\end{abstract}

Resumo

Este trabalho relata o estudo da síntese de peneiras moleculares semelhantes à MCM-41, empregando cinza da casca de arroz como única fonte de sílica. Para critérios de comparação uma síntese foi realizada com sílica comercial aerosil 200. A sílica da casca de arroz foi obtida mediante tratamento térmico a $600{ }^{\circ} \mathrm{C}$ e lixiviação em refluxo por $2 \mathrm{~h} \mathrm{com} \mathrm{HCl} 1 \mathrm{~mol} / \mathrm{L}$ e empregada na sintese. As amostras preparadas foram caracterizadas por adsorção de $N_{2}$, difração de raios $X$, microscopia eletrônica de varredura $(M E V)$ e termogravimetria. Por meio das isotermas de adsorção, do tipo IV, observa-se a formação de material mesoporoso. Nos difratogramas de raios $X$ é identificada a formação hexagonal unidirecional de poros, indicando que material apresenta semelhanças com a MCM-41. Por MEV observa-se que a casca de arroz possui aspecto fibroso e que a sintese empregando a casca de arroz calcinada e lixiviada não reagiu na sua totalidade devido a dissolução parcial da sílica.

Palavras-chave: MCM-41, cinza da casca de arroz, mesoporos.

\section{INTRODUCTION}

The search for the use and exploitation of industrial and agricultural wastes of commercial interest is increasingly intense. This can be observed especially in agribusiness, representing a potential source of income and a way of reducing waste generation and environmental impacts. Moreover, the increasing improvement of the ceramics industry, the need for technological advancements for a better cost / benefit ratio of materials have encouraged the diversification in the supply of raw materials, seeking to integrate different production chains. Creating products from this waste adds value and creates wealth, which makes them very attractive. Reducing waste generation in industrial and agricultural processes, better using them, creating routes with lower cost, cheaper products and reducing the release of wastes into the environment are the goal of any economy seeking modernization and preservation of natural resources. In the Brazilian context, one of these examples is rice husk.
According to the National Supply Company [1], the national production of paddy rice for the year 2011 was estimated at 13,733,200 ton. In rice husks, the main constituents are cellulose (about 48\%), lignin (about 23\%) and the rest are other organic compounds such as oils and proteins [2]. In the plant straw, which corresponds to about $10 \%$ by weight of paddy rice [3], there is a high concentration of silica, with approximately $13 \%$ by weight. Other compounds such as $\mathrm{K}_{2} \mathrm{O}, \mathrm{CaO}, \mathrm{Na}_{2} \mathrm{O}, \mathrm{Al}_{2} \mathrm{O}_{3}, \mathrm{MnO}, \mathrm{P}_{2} \mathrm{O}_{5}$ are also found in proportions that depend on soil nature and plant variety. These compounds are considered impurities, since they modify the properties of silica [4]. Their burning under controlled conditions produces a black residue, the rice husk ash, which is rich in amorphous silica.

Among mesoporous materials, M41S-type materials stand out, which were discovered by Mobil Oil Co. in 1992 [5]. MCM-41 (Mobil Composition of Matter) is a mesoporous molecular sieve with hexagonal arrangement of pores, specific area over $700 \mathrm{~m}^{2} / \mathrm{g}$, controllable pore size. Due 
to these characteristics, these materials are used in various processes such as adsorption [6], catalysis [7], controlled release of drugs [8], gas capture [9], enzyme immobilization [10], among others. The synthesis of these materials requires a source of silica, usually commercial, which is the structure directing agent, a solvent and a mineraliser agent. There are reports in literature on the use of alternative sources of silica for the synthesis of these materials [11-13]. Some researchers use rice husks together with some other source of silica, usually commercial, but syntheses are performed in several days $[14,15]$.

This work aims the synthesis of materials similar to MCM-41 in short periods of time, using rice husk as a single source of silica in their composition. Thus, this study searches to add value to rice husk, an abundant and cheap material, considered a byproduct or waste from the rice beneficiation process, which can be used in adsorption and catalysis processes.

\section{EXPERIMENTAL STAGE}

The literature shows that it is possible to obtain pure silica from rice husk [16]. Thus, rice husk was submitted to two treatment processes, thermal and chemical. In the thermal treatment, based on adopted procedures, husk was calcined in heating rate of $4{ }^{\circ} \mathrm{C} / \mathrm{min}$ up to $600^{\circ} \mathrm{C}$, where it remained for additional $4 \mathrm{~h}$. Later the rice husk was submitted to chemical treatment; $25 \mathrm{~g}$ of calcined rice husk was leached in reflux at $100{ }^{\circ} \mathrm{C}$ with $500 \mathrm{~mL}$ of $\mathrm{HCl} 1 \mathrm{~mol} / \mathrm{L}$ for $2 \mathrm{~h}$. Afterwards the residual husk was washed with deionized water and dried at $110{ }^{\circ} \mathrm{C}$ overnight, which was called calcined and leached rice husk (CACL). The synthesis of MCM-41 was based on the reported procedure [17]. Two solutions were prepared: solution A: $5 \mathrm{~g}$ of hexadecyltrimethylammonium bromide (Aldrich) are dissolved in $33.5 \mathrm{~g}$ of distilled water. Solution $\mathrm{B}$ : on $8.65 \mathrm{~g}$ of a solution of $25 \%$ tetramethylammonium hydroxide (Aldrich), $0.96 \mathrm{~g}$ silica from rice husks were dispersed. Solution A was added to solution B, hydrolyzing additional $4.52 \mathrm{~g}$ of rice husk, leaving under stirring for $1 \mathrm{~h}$.
The resulting gel was transferred to autoclaves with teflon bottom and led to the oven for $24 \mathrm{~h}$ at $135{ }^{\circ} \mathrm{C}$. The sample was called CACLMCM-41. Comparing to this procedure, the same methodology was tested, using silica Aerosil 200 as source of silica, which was named SiMCM-41. All samples were calcined in fixed bed reactor under flowing nitrogen and synthetic air at $550^{\circ} \mathrm{C} / 11 \mathrm{~h}$.

\section{Characterization of samples}

XRD analyses were performed in a Miniflex II Rigaku diffractometer with Ni filter and $\mathrm{Cu}-\mathrm{k} \alpha$ radiation $(\lambda=1.54$ $\AA$ ). For measurements of nitrogen adsorption, a Quanta Chrome Nova 1000 device was used; samples were pretreated for $3 \mathrm{~h}$ at $300{ }^{\circ} \mathrm{C}$ under vacuum. Scanning electron microscopy (SEM) was performed on a ESEM-XL30 Philips microscope, and samples were coated with a gold layer to prevent surface charges that could lead to image distortion. Thermogravimetric analyses were performed on a TGA-50H Shimadzu thermal analyzer with heating rate $10^{\circ} \mathrm{C} / \mathrm{min}$ under synthetic air flow.

\section{RESULTS AND DISCUSSION}

Fig. 1 shows the $\mathrm{X}$-ray diffractograms of the synthesized samples. It was observed in image (a) the synthesized sample CACLMCM-41, where the existence of the plane $\mathrm{d}_{100}$ indicates the formation of mesoporous material with hexagonal structure. Planes $\mathrm{d}_{100}$ and $\mathrm{d}_{200}$ indicate the degree of organization of the pore system, and in comparison with standard sample SiMCM-41, image (b), this image shows that these reflections are little resolved, indicating that the material has a low-order hexagonal pore system, as already reported [18]. The absence of reflections at higher angles indicates that the material is not crystalline; however, there is a hexagonal arrangement, which also can be observed by the high intensity of the first reflection of plane $d_{100}$. Furthermore, it could be concluded that the materials have good thermal stability, since they were submitted to
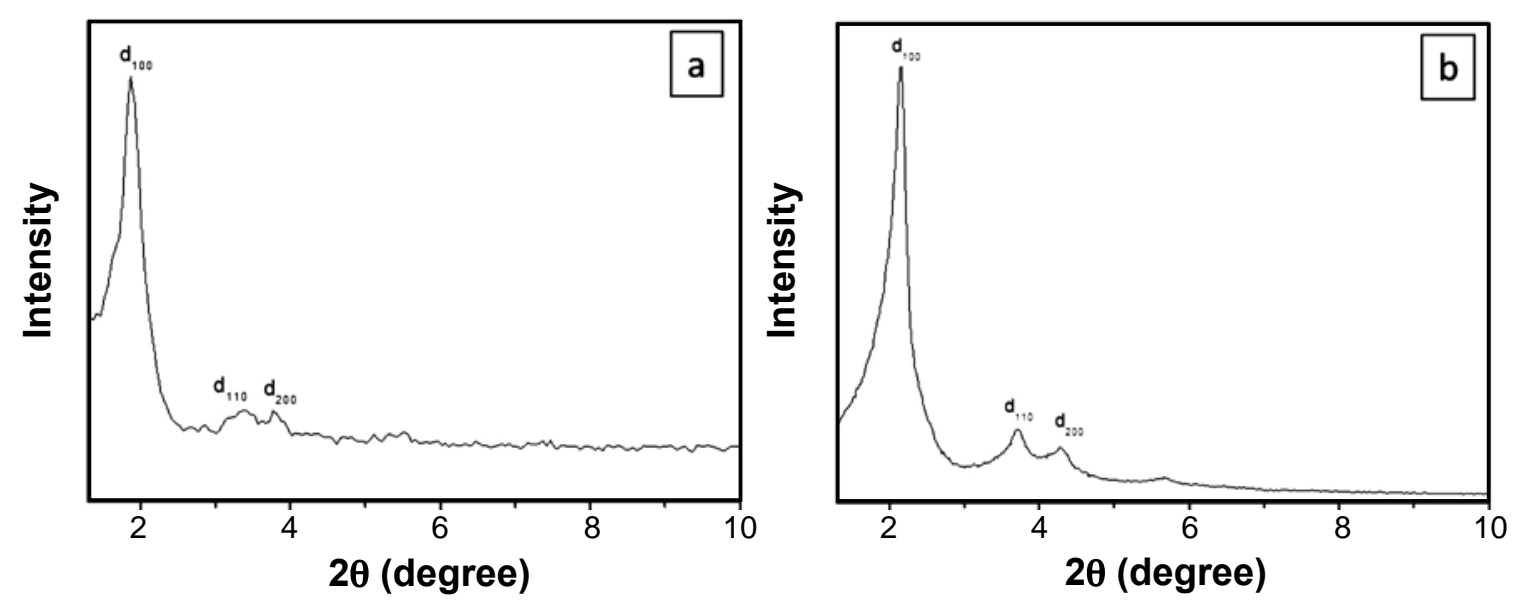

Figure 1: X-ray diffraction patterns of synthesized samples. Image (a) CACLMCM-41 and (b) SiMCM-41. [Figura 1: Difratogramas de raios X das amostras sintetizadas. Imagem (a) CACLMCM-41 e (b) SiMCM-41.] 
calcination at maximum temperatures of $550{ }^{\circ} \mathrm{C}$, and there was no destruction of their structure.

Table I shows a comparison between the two procedures. The analyses of $\mathrm{N}_{2}$ adsorption showed that the reference material, SiMCM-41, has higher specific area compared to CACLMCM-41. Despite this difference, the material has high specific area, a feature of mesoporous materials, which can also be proved by type-IV isotherms, characterizing its mesoporosity in Fig. 6. The newtork parameter can be calculated in a simplified manner through the expression $\mathrm{a}_{0}=$ $2 \mathrm{~d}_{100} / 3^{1 / 2}$, where $\mathrm{d}_{100}$ corresponds to the diffraction plane $\left(\mathrm{d}_{100}\right)$, related to the pore diameter $\mathrm{Dp}$, estimated by the Barrett-Joyner-Halenda method ( BJH), and (Wt) as the wall thickness, calculated as the difference between the newtork parameter $\mathrm{a}_{0}$ and the pore diameter $\mathrm{Dp}$.

Table I - Comparison between both synthesized materials. [Tabela I - Comparação entre ambos materiais sintetizados.]

\begin{tabular}{cccccc}
\hline Sample & $\begin{array}{c}\text { BET area } \\
\left(\mathrm{m}^{2} / \mathrm{g}\right)\end{array}$ & $\begin{array}{c}\mathrm{d}_{100} \\
(\mathrm{~nm})\end{array}$ & $\begin{array}{c}\mathrm{a}_{0} \\
(\mathrm{~nm})\end{array}$ & $\begin{array}{c}\mathrm{Dp} \\
(\mathrm{nm})\end{array}$ & $\begin{array}{c}\mathrm{Wt} \\
(\mathrm{nm})\end{array}$ \\
\hline SiMCM-41 & 1086 & 4.43 & 5.11 & 3.2 & 1.91 \\
CACLMCM-41 & 468 & 4.69 & 5.41 & 3.2 & 2.21 \\
\hline
\end{tabular}

The similarity between the values of pore diameter found in samples, that occurs due to the synthesis temperature, is primarily due to the use of the structure directing agent, hexadecyltrimethylammonium bromide, in which the pore size is controlled by the size of the alkyl chain, both factors are similar in the two syntheses.

For average wall thickness values, $\mathrm{Wt}$, there is an increase of $0.30 \mathrm{~nm}$ in sample CACLMCM-41, which is probably due to the poor hexagonal organization of the unidirectional system of pores.

Scanning electron microscopy analysis of calcined and leached rice husk (CACL), Fig. 3a, indicates clusters and through the insert, irregular morphology of the material was observed, as already reported [19]. The SEM image obtained for CACLMCM-41, Fig. 3b, shows clusters with irregular morphology with particles larger than $50 \mu \mathrm{m}$. The fibrous form of swollen appearance, as seen in the insert, refers to channels where the cellulosic material obtained from rice husk was found occluded prior to heat treatment at $600{ }^{\circ} \mathrm{C}$, as already reported [20]. The fibrous form also indicates
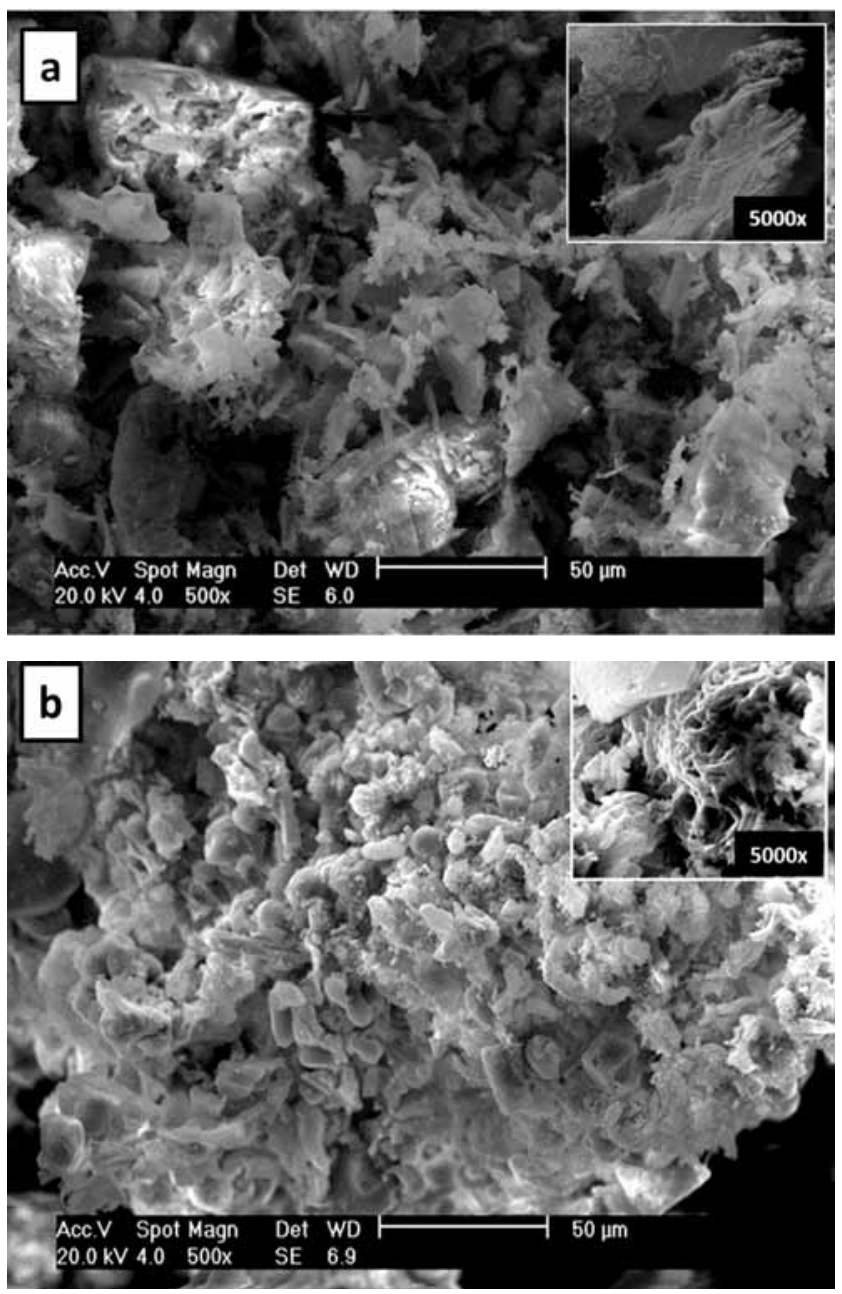

Figure 3: Scanning electron microscopy micrographs of samples (a) CACL and (b) CACLMCM-41.

[Figura 3: Micrografias obtidas por microscopia eletrônica de varredura das amostras (a) CACL e (b) CACLMCM-41.]
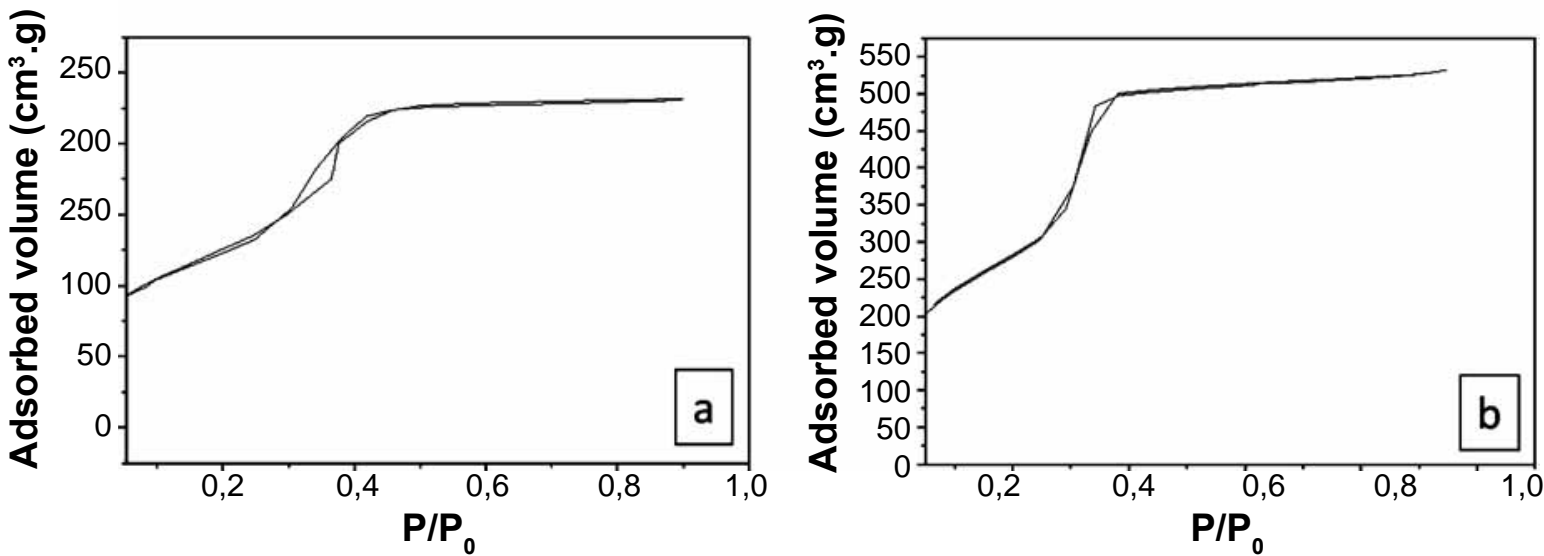

Figure 2: $\mathrm{N}_{2}$ adsorption and desorption isotherms of synthesized materials. Image (a) CACLMCM-41 and (b) SiMCM-41. [Figura 2: Isotermas de adsorção e dessorção de $N_{2}$ dos materiais sintetizados. Imagem (a) CACLMCM-41 e (b) SiMCM-41.] 

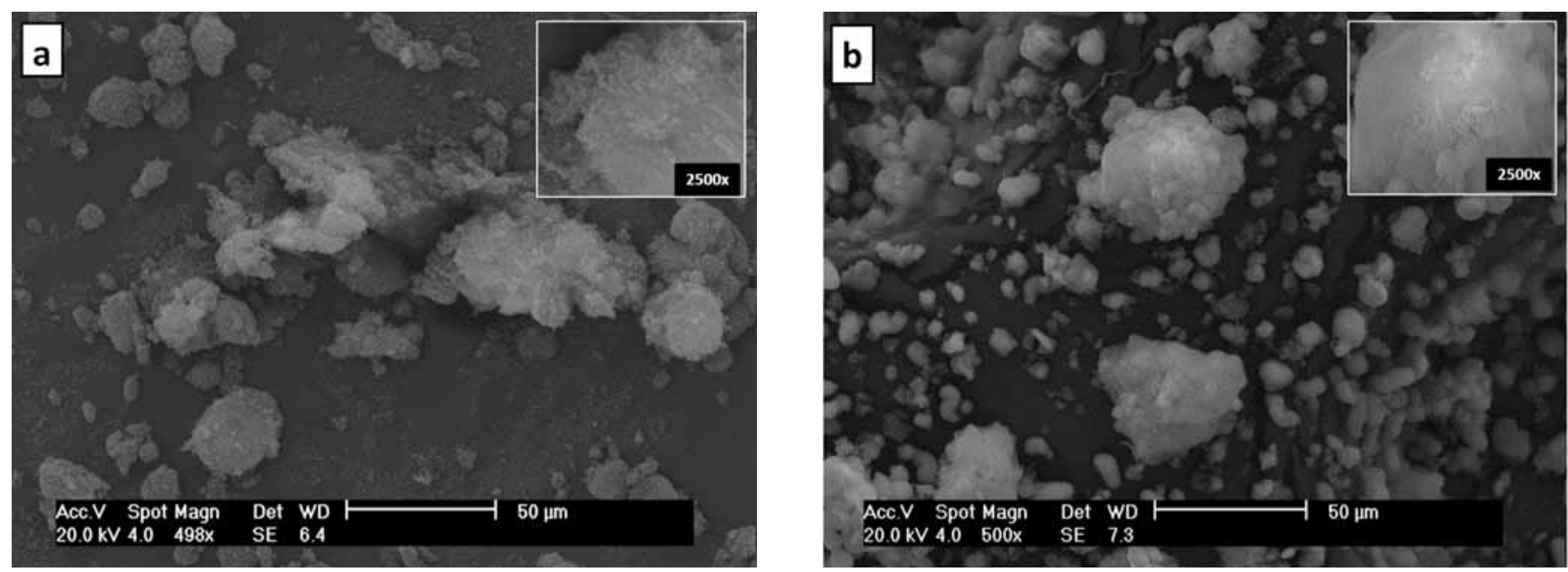

Figure 4: Scanning electron microscopy of samples (a) aerosil 200 commercial silica and (b) standard sample SiMCM-41.

[Figura 4: : Micrografias obtidas por microscopia eletrônica de varredura das amostras (a) sílica comercial aerosil 200 e (b) amostra padrão SiMCM-41.]
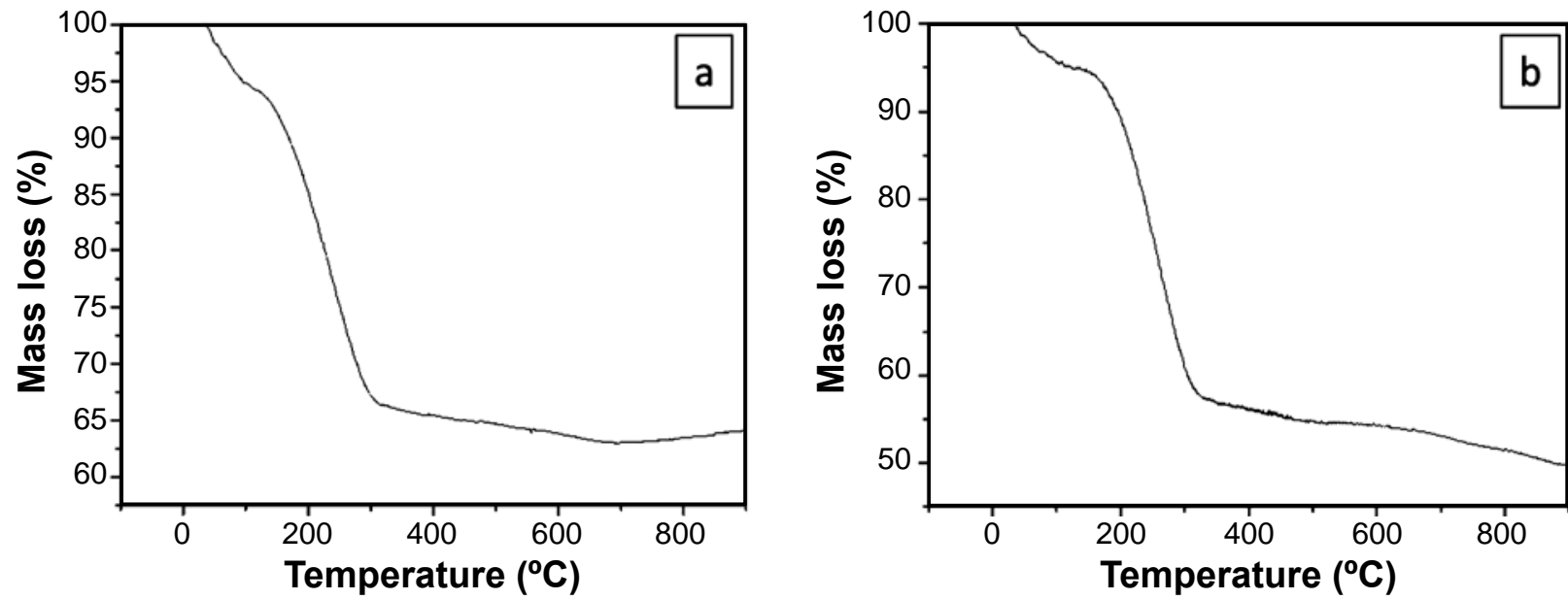

Figure 5: Thermogravimetric curves of synthesized samples (a) CACLMCM-41 and (b) SiMCM-41.

[Figura 5: Curvas termogravimétricas das amostras sintetizadas (a) CACLMCM-41 e (b) SiMCM-41.]

that, possibly, chemical treatment did not totally dissolved silica present in rice husk, indicating that the material did not react in its entirety.

Microscopy of aerosil 200 commercial silica samples (image a) and synthesized sample SiMCM-41 (image b) are shown in Fig. 4. The starting commercial silica (image a) has greater porosity, which facilitates the dissolution of silica and its reaction with the base. Image $b$ shows that the standard synthesized sample SiMCM-41 displays particle with size of $50 \mu \mathrm{m}$ and particles with size of $7 \mu \mathrm{m}$ in larger amounts. Comparing to sample CACLMCM- 41 , there is a better distribution of less clustered particles, which can be explained by the fact that aerosil 200 commercial silica is more reactive than CACL.

Fig. 5 shows the results of thermogravimetric analysis of CACLMCM 41 and SiMCM-41 samples, respectively. MCM-41 has three mass loss events [21]. From 25 to $134^{\circ} \mathrm{C}$ there is desorption of water physically adsorbed, with mass losses of $5 \%$ in both samples. From 134 to $345{ }^{\circ} \mathrm{C}$ there is decomposition of hexagonally arranged surfactant, indicating that the sample SiMCM-41 has mass loss approximately $9 \%$ higher than sample CACLMCM-41, meaning that it has a larger amount of template and, consequently, increased formation of mesopores. These results are in agreement with specific area and X-ray diffraction analyses. Above $345^{\circ} \mathrm{C}$ the mass loss occurs due to condensation of silanol groups present on the network.

\section{CONCLUSIONS}

Calcined and leached rice husk may be used for the formation of mesoporous materials. The synthesis provided material similar to the reference sample, showing median values of specific area, type-IV isotherms and pore hexagonal system, typical of MCM-41-type mesoporous materials. The scanning electron microscopy images show that the material did not react entirely due to the uncomplete dissolution of the silica present in rice husk. The thermogravimetric analysis 
show that mass losses are similar to that of the the standard sample, confirming the possibility of synthesis.

\section{ACKNOWLEDGMENTS}

To Capes for the scholarship, to UFRN and URI (Campus-Erechim) for the facilities.

\section{REFERENCES}

[1] CONAB - Companhia Nacional de Abastecimento, Acompanhamento de safra brasileira: grãos, Quarto levantamento, janeiro 2011, Brasília, Conab (2011).

[2] J. James, M. S. Rao, Thermochim. Acta 97 (1986) 329336.

[3] N. Yalçin, V. Sevinç, Ceram. Int. 27 (2001) 219-224.

[4] M. Persegil, M. Souza, W. Magalhães, Adv. Mater. Res. 5 (2002) 467.

[5] C. T. Kresg, M. E. Leonowicz, W. J. Roth, J. C. Vartuli, J. S. Beck, Nature 359 (1992) 710-712.

[6] S. Eftekhari, A. Habibi-Yangjeh, Sh. Sohrabnezhad, J. Hazard. Mater. 178 (2010) 349-355.

[7] W. Zhang, J. Wang, P. T. Tanev, T. J. Pinnavaia, J. Chem. Soc. - Chem. Comm. (1996) 979-980.

[8] M. Vallet-Regi, A. Rámila, R. P. del Real, J. PérezPariente. Chem. Mater. 13 (2001).

[9] M. R. Mello, D. Phanon, G. Q. Silveira, P. L. Llewellyn, C. M. Ronconi, Microporous Mesoporous Mater. 143 (2011)
174-179.

[10] J. F. Diaz, K. J. Balkus, J. Mol. Cat. B: Enzymatic 2 (1996) 115-126.

[11] F. Kang, Q. Wang, S. Xiang, Mater. Lett. 59 (2005) 1426-1429.

[12] K. S. Hui, C. Y. H. Chao, J. Hazard. Mater. 137 (2006) $1135-1148$

[13] M. L. P. Silva, Tese Dr., UFRN, Natal, RN (2009).

[14] R. M. Braga, D. A. A. Melo, M. A. F. Melo, J. M. F. Barros, G. P. Oliveira, R. G. S. A. Filho, Anais $22^{\circ}$ Cong. Ibero-americano Catálise (2010).

[15] M. Halina, S. Ramesh, B. Shahida, A. Y. Mohd, J. Mater. Process. Techn. 186 (2007) 8-13.

[16] E. L. Foletto, R. Hoffmann, R. S. Hoffmann, U. L. Portugal Jr., S. L. Jahn, Quim. Nova, 28, 6 (2005), 10551060.

[17] M. T. N. Villalba, Tese Dr., ITQ, Valência, Espanha (1995).

[18] C. Y. Chen, S. Q. Xiao, M. E. Davis, Microporous Mater. 4 (1995) 1-20.

[19] D. I. Petkowicz., R. T. Rigo, C. Ratdke, S. B. C. Pergher, J. H. Z. Santos, Microporous Mesoporous Mater. 116 (2008) 548-554.

[20] A. Bharadwaj, Y. Wang, S. Sridhar, V. S. Arunachalam, Current Sci. 87 (2008) 981-986.

[21] C. Y. Chen, H. X. Li, M. E. Davis, Microporous Mater. 2 (1993) 17-26.

(Rec. 20/03/2012, Ac. 18/06/2012) 